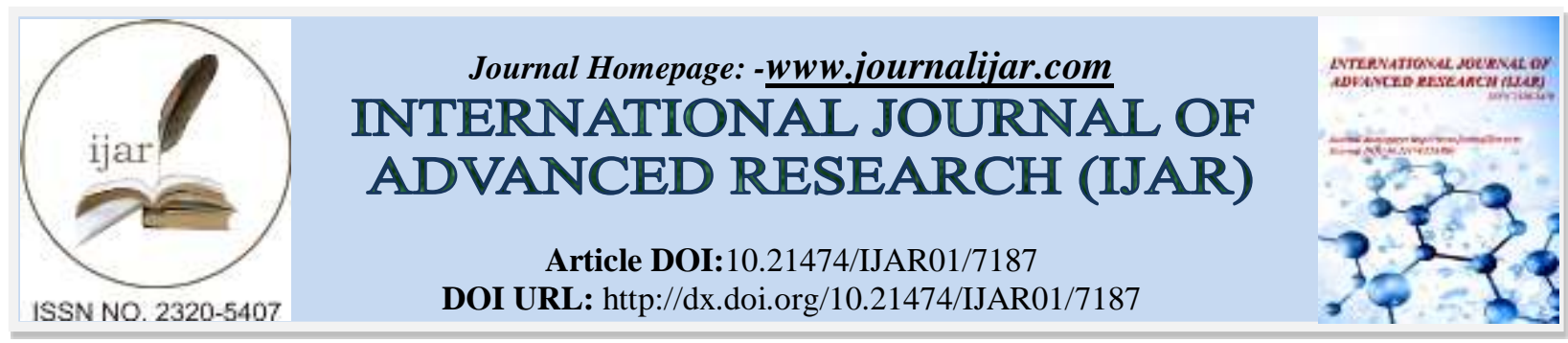

RESEARCH ARTICLE

\title{
EVALUATION OF PLACEMENT SITES AND FORMS OF UREA FERTILIZER FOR IMPROVED NITROGEN USE EFFICIENCY IN HYBRID MAIZE CULTIVATION.
}

\author{
Thant Lwin Oo ${ }^{1}$, Than Da Min ${ }^{2}$, Kyaw Kyaw Win ${ }^{2}$ and Mie Mie Aung ${ }^{4}$. \\ 1. Research based PhD student, Yezin Agricultural University, Myanmar. \\ 2. Professor, Agronomy, Yezin Agricultural University, Myanmar. \\ 3. Professor, Plant Breeding, Physiology and Ecology, Yezin Agricultural University, Myanmar.
}

\section{Manuscript Info}

Manuscript History

Received: $x x x x x x x x x x x x x x x$

Final Accepted: $x x x x x x x x x x x$

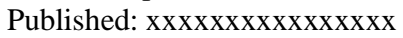

Keywords:-

Hybrid maize, Nitrogen Uptake

Efficiency, Nitrogen Utilization

Efficiency, Briquette, Prilled, Urea

fertilizer.

\begin{abstract}
Field experiments were carried out at Department of Agricultural Research, Head Quarter, Yezin and Tatkon Agricultural Research Farm, during winter season of 2017 to investigate the effect of placement pattern and form of urea fertilizer by using same fertilizer rate. Nitrogen fertilizer rate of $166.29 \mathrm{~kg} \mathrm{~N} \mathrm{ha}^{-1}$ with two forms of nitrogen fertilizer (Briquette urea and Prilled urea) and three placement patterns; between plants (P1), between rows (P2) and between plants and rows (P3)were used. The $3 \times 2$ factorial arrangements were assigned in the randomized complete block design with 4 replications in both experimental sites. Mean effects of placement sites of applied nitrogen on seed yield of maize were not significant in this study. The highest mean values of seed yield were resulted at the placement pattern of P3 in Yezin $\left(9015 \mathrm{~kg} \mathrm{ha}^{-1}\right)$ and Tatkon $\left(9980 \mathrm{~kg} \mathrm{ha}^{-1}\right)$. Briquette urea gave generally higher yield than those of prilled urea in both sites. Non-significant interaction was observed between placement patterns and form of urea fertilizer applied in the variation of hybrid maize seed yield. The nitrogen uptake efficiency of the plant was significantly higher in application of briquette urea for both trials. But the nitrogen utilization efficiency for the applications of briquette was significantly lower than prilled urea treated plots. It could be due to the split application of prilled urea at three different growth stages. Application of the entire $\mathrm{N}$ in the form of briquette at basal with the rate of $166.29 \mathrm{~kg} \mathrm{~N} \mathrm{ha}^{-1}$ showed better performance with respect to yield and nitrogen uptake efficiency of Yezin Hybrid Maize-10.
\end{abstract}

Copy Right, IJAR, 2018,. All rights reserved.

\section{Introduction:-}

Maize is the second principal cereal crop after rice in Myanmar. Nitrogen is the most limiting nutrients in maize production. Due to the volatile nature of $\mathrm{N}$ fertilizers, it has been estimated that between $35 \%$ and $65 \%$ of applied nitrogen is lost from soil systems (Cassman et al., 2002; Jayasundara et al., 2007; Koocheki et al., 2013). Nitrogen losses from denitrification, volatilization, and leaching effects detrimental to the environment and it have been well documented. Bodirsky et al. (2014) pointed that in order to feed the world and keep nitrogen pollution levels below 
critical levels, world $\mathrm{N}$ losses need to decrease to less than $15 \%$ by 2050 . Thus, there is need to develop technologies that result in the most efficient use of the fertilizer $\mathrm{N}$.

The International Fertilizer Development Center (IFDC) conducted many research and showed that fertilizer deep placement (FDP) could be one of the best management techniques to achieve the multiple benefits of increasing grain yield, farm profits, and nitrogen use efficiency while reducing negative environmental effects (IFDC, 2013). Urea Deep Placement (UDP) in lowland rice fields has been widely recognized as an effective management practice that reduces fertilizer (urea) use by $25-40 \%$ and increases yield by an average of 15-20\%. In Bangladesh, 15-20 percent increases in maize yields have been achieved with fertilizer deep placement (FDP), while farmers use 15-20 percent less N (IFDC, 2013). Fertilizer deep placement with briquette urea is a technology that can be manipulated to better match $\mathrm{N}$ availability to crop needs in Myanmar.

\section{Objective:-}

The present study aims to investigate the efficient nitrogen fertilizer form for maize production and to determine the appropriate fertilizer placement pattern to get high yield.

\section{Materials And Methods:-}

The experiments were conducted during winter season 2017 at the Department of Agricultural Research, Yezin $\left(19^{\circ} 57^{\prime} \mathrm{N}, 96^{\circ} 16^{\prime} \mathrm{E}\right.$, elevation $\left.130.85 \mathrm{~m}\right)$ and Tatkon Agricultural Research Farm (20 07' $\mathrm{N}, 96^{\circ} 12^{\prime} \mathrm{E}$, elevation $155.25 \mathrm{~m})$. The $3 \times 2$ factorial arrangements were assigned in the Randomized Complete Block design with 4 replications in both experimental sites. Three placement patterns of Urea; between plants (P1), between rows (P2) and between plants and rows (P3) were used as one factor. Nitrogen fertilizer rate of $166.29 \mathrm{~kg} \mathrm{~N}^{-1}{ }^{-1}$ was used with two forms of nitrogen fertilizer (Briquette urea and Prilled urea) were used as another factor. Used cultivar in the experiment was single-crossed Yezin Hybrid Maize-10. Selected soil chemical and physical characteristics for the two research stations soil are presented in Table 1. The Prilled Urea (PU) is the most common form of urea available in the market and contains $46 \%$ nitrogen $(\mathrm{N})$. The Briquette Urea (BU) is manufactured from a physical modification of ordinary urea fertilizer. The International Fertilizer Development Center (IFDC) has developed it. Its nature and properties are similar to that of PU but its granule size is bigger and condensed in shape containing $46 \% \mathrm{~N}$. The weight of briquette used in this study was $1.8 \mathrm{~g}$ and $2.7 \mathrm{~g}$. The ordinary triple super phosphate (TSP) $123.5 \mathrm{~kg} \mathrm{ha}^{-1}$ and Muriate of Potash (MOP) $123.5 \mathrm{~kg} \mathrm{ha}^{-1}$ were used for source of nutrient at basal. For PU treatments, $\mathrm{N}$ fertilizer (166.29 $\mathrm{kg} \mathrm{N}$ ha $^{-1}$ ) was applied in three equal split amount at basal, 21 days and 35 days after sowing. BU was applied at sowing time inserted into 7-10 $\mathrm{cm}$ deep with three different patterns.

Each plot comprised of 8 rows with $5 \mathrm{~m}$ long and spacing was $0.76 \mathrm{~m}$ between row and $0.23 \mathrm{~m}$ within plants. The standard procedure for maize was carried out during the crop stand. Agronomic characteristics and yield component characters were recorded. As $\mathrm{N}$ fertilizer was applied in different plots at different forms and site, according to Moll et al., (1982) two primary components of $\mathrm{N}$ use efficiency; Nitrogen uptake efficiency (NUpE) and Nitrogen utilization efficiency (NUtE) were recorded and calculated as;

1. Efficiency of absorption or uptake $(\mathrm{NUpE})=(\mathrm{Nt} / \mathrm{Ns})$,

2. Efficiency with which $\mathrm{N}$ absorbed is utilized to produce grain $(\mathrm{NUtE})=(\mathrm{Gw} / \mathrm{Nt})$ where, $\mathrm{Nt}=$ total $\mathrm{N}$ in the plant at maturity (grain + stover);

$\mathrm{Ns}=$ nitrogen supply or rate of fertilizer $\mathrm{N}$;

$\mathrm{Gw}=$ grain weight.

Data analysis was done by using SAS program version 9.1(SAS Institute 2001) for analysis of variance and mean comparison.

Table 1:-Physio-chemical properties of experimental soils

\begin{tabular}{|l|c|c|}
\hline \multicolumn{1}{|c|}{ Properties } & Yezin & Tatkon \\
\hline Soil Texture & Loamy Sand & Sandy Loam \\
\hline Sand \% & 87 & 72 \\
\hline Silt \% & 5 & 10 \\
\hline Clay \% & 8 & 18 \\
\hline
\end{tabular}




\begin{tabular}{|l|c|c|}
\hline Soil $\mathrm{pH}$ & 6.3 & 7.2 \\
\hline Available N (mg/kg) & 74 & 62 \\
\hline Available P $(\mathrm{mg} / \mathrm{kg})$ & 20 & 4 \\
\hline Available K (mg/kg) & 113 & 98 \\
\hline Organic Matter $(\%)$ & 2.5 & 2.2 \\
\hline
\end{tabular}

\section{Results And Discussions:-}

Nitrogen placement patterns were not significantly affected yield in Yezin and Tatkon (Table 2). The placement pattern P3 (Urea applied between plants and between rows) provided maximum yield (9015 kg ha ${ }^{-1}$ in Yezin and $9980 \mathrm{~kg} \mathrm{ha}^{-1}$ in Tatkon) which was not statistically significant from others placement pattern of P1(Urea applied between plants) and P2 (Urea applied between rows). The lowest value of yield $8427 \mathrm{~kg} \mathrm{ha}^{-1}$ in Yezin and $8824 \mathrm{~kg}$ $\mathrm{ha}^{-1}$ in Tatkon was found in the placement pattern of P2. It was cleared that nitrogen fertilizer is needed to place between plants as well as between rows to get better yield in hybrid maize.

Form of nitrogen fertilizer application (Briquette urea and Prilled urea) for three different placement patterns on yield was statistically significant only in Yezin trials (Table 2). But, the briquette urea treated plots were gained more value in yield than prilled urea treated plots in both locations. The results pointed that briquette form of urea application at once in basal could be cost effective and more yield than split prilled $\mathrm{N}$ application and this result was not in line with Niaz et al., 2015. They showed that applying the entire $\mathrm{N}$ rate at seedbed preparation was least effective way of $\mathrm{N}$ management with respect to yield and $\mathrm{N}$ use efficiency of maize crop and application of entire $\mathrm{N}$ at planting did not appear as a wise choice.

The effect of interaction between nitrogen fertilizer placement site and form of nitrogen fertilizer application was not significant on yield in both trials. The interaction of P3 (Urea applied between plants and between rows) with briquette form of urea gave the highest yield (9824 kg ha-1) in Yezin (Fig. 1) and $10737 \mathrm{~kg} \mathrm{ha}^{-1}$ in Tatkon (Fig. 2). At the same fertilizer rates, briquette form of application intended to increase yield in both trials.

The form of nitrogen fertilizer significantly affected nitrogen uptake efficiency (NUpE), and nitrogen utilization efficiency (NUtE) in both trials. With briquette form of $\mathrm{N}$ fertilizer significantly increased NUpE $\left(0.83 \mathrm{~kg}^{-1} \mathrm{~kg}^{-1}\right.$ in Yezin and $1.09 \mathrm{~kg}^{-1} \mathrm{~kg}^{-1}$ in Tatkon) than with prilled urea treated plots $\left(0.73 \mathrm{~kg}^{-1} \mathrm{~kg}^{-1}\right.$ in Yezin and $0.91 \mathrm{~kg}^{-1} \mathrm{~kg}^{-1}$ in Tatkon) (Table 2). The mean value of NUpE which placed urea fertilizer in between plants (P1) showed the highest $\left(0.83 \mathrm{~kg}^{-1} \mathrm{~kg}^{-1}\right)$ in Yezin and placement of urea in between rows (P2) gave the highest $\left(1.26 \mathrm{~kg}^{-1} \mathrm{~kg}^{-1}\right)$ in Tatkon. By using prilled urea, placement pattern P3 gave the highest NUpE $\left(0.77 \mathrm{~kg}^{-1} \mathrm{~kg}^{-1}\right)$ but application of briquette form which placed in between plants (P1) significantly enhanced NUpE $\left(0.97 \mathrm{~kg}^{-1} \mathrm{~kg}^{-1}\right)$ in Yezin (Fig 3). Whether using briquette or prilled urea, which placed between rows gave the highest NUpE value of $1.47 \mathrm{~kg}^{-1} \mathrm{~kg}^{-1}$ for briquette and $1.05 \mathrm{~kg}^{-1} \mathrm{~kg}^{-1}$ for prilled urea treated plots in Tatkon (Fig 4). The dissimilar results came from two tested site (Yezin and Tatkon) could also be the different physio-chemical properties of soil (Table 1). Since NUpE is a measure how well a plant uses $\mathrm{N}$ to stimulate growth, it is dependent on the physiological processes of the plant.

The influence of agronomic practices and environmental factors on NUpE has been widely reported (Jayasundara et al., 2007; McTaggart \& Smith, 1995; Subedi \& Ma, 2005; Wang \& Below, 1992). High plant populations and narrow row spacing have been shown to positively influence NUpE (Barbieri et al., 2008; Ciampitti \& Vyn, 2011). Additionally, the importance of root architecture, agronomic fertilization practices, and environmental conditions have been widely cited as influential on the rate of NUpE (Kirda et al., 2005; Lynch, 2013; McTaggart \& Smith, 1995; Mi et al., 2010; Zotarelli et al., 2008).

The mean value of NUtE significantly increased in application of prilled urea form for both trials. It could be the application of split prilled urea fertilizer. NUtE is effectively a measure of the sink capacity of the plant and how well it can remobilize accumulated $\mathrm{N}$ stored in the vegetative tissue to the ear. Pollmer et al., (1979) said that the utilization efficiency is indicative of how the $\mathrm{N}$ in the plant is used to stimulate earshot and kernel growth. Masclaux-Daubresse et al., (2010) considered that NUtE is governed by complex network of nitrogen cycling enzymes and processes. Thus, few inconsistency results came out for NUtE in both locations. The application of urea fertilizer between rows (P2) provided the maximum value of NUtE value $\left(71.13 \mathrm{~kg}^{-1} \mathrm{~kg}^{-1}\right)$ in Yezin and the application of urea fertilizer between plants (P1) obtained the maximum NUtE of $\left(67.51 \mathrm{~kg}^{-1} \mathrm{~kg}^{-1}\right)$ in Tatkon (Table 
2). The significant effect was given by the interaction between form of nitrogen application and placement patterns of urea fertilizer. The highest result on NUtE $\left(77.38 \mathrm{~kg}^{-1} \mathrm{~kg}^{-1}\right)$ was found in the placement pattern P1 (between plants) with prilled urea form in Yezin trial (Fig 5). Using briquette urea placed between plants (P1) gave the highest mean value $\left(67.61 \mathrm{~kg}^{-1} \mathrm{~kg}^{-1}\right)$ in Tatkon location (Fig 6).

Table 2:-Mean effect of placement sites and form of urea fertilizer on seed yield and nitrogen uptake efficiency (NupE) and nitrogen utilization efficiency (NutE) of hybrid maize in Yezin, the Department of Agricultural Research and Tatkon Agricultural Research Farm during winter season of 2017

\begin{tabular}{|l|c|c|c|c|c|c|}
\hline & \multicolumn{2}{|c|}{$\begin{array}{c}\text { Seed Yield } \\
\left(\mathrm{kg} \mathrm{ha}^{-1}\right)\end{array}$} & \multicolumn{2}{c|}{$\begin{array}{c}\mathrm{NUpE} \\
\left(\mathrm{kg}^{-1} \mathrm{~kg}^{-1}\right)\end{array}$} & \multicolumn{2}{c|}{$\begin{array}{c}\text { NUtE } \\
\left(\mathrm{kg}^{-1} \mathrm{~kg}^{-1}\right)\end{array}$} \\
\hline Placement of Urea (P) & Yezin & Tatkon & Yezin & Tatkon & Yezin & Tatkon \\
\hline Between Plants & 8650.2 & 9824.9 & 0.83 & 0.85 & 66.79 & 67.51 \\
\hline Between Rows & 8427.4 & 8823.7 & 0.76 & 1.26 & 71.13 & 49.12 \\
\hline Between Plants and Rows & 9015.4 & 9980.0 & 0.75 & 0.90 & 65.36 & 60.52 \\
\hline LSD $_{0.05}{ }^{(1)}$ & - & - & - & 0.11 & 3.07 & 2.49 \\
\hline Form of Urea (F) & & & & & & \\
\hline Briquette & 9243.0 & 9912.1 & 0.83 & 1.09 & 65.79 & 56.58 \\
\hline Prilled & 8152.3 & 9173.6 & 0.73 & 0.91 & 69.72 & 61.51 \\
\hline LSD $_{0.05}{ }^{(1)}$ & 853.7 & - & 0.06 & 0.09 & 2.51 & 2.03 \\
\hline Pr>F & & & & & & \\
\hline P & 0.497 & 0.1037 & 0.0729 & $<.0001$ & 0.0032 & $<.0001$ \\
\hline F & 0.0157 & 0.1182 & 0.0025 & 0.0040 & 0.0046 & 0.0001 \\
\hline P x F & 0.6501 & 0.4065 & 0.0008 & 0.0039 & $<.0001$ & 0.0019 \\
\hline CV $(\%)$ & 11.28 & 11.44 & 8.83 & 10.01 & 4.26 & 3.95 \\
\hline
\end{tabular}

${ }^{(1)}$ Least Significant Difference at $5 \%$ probability.
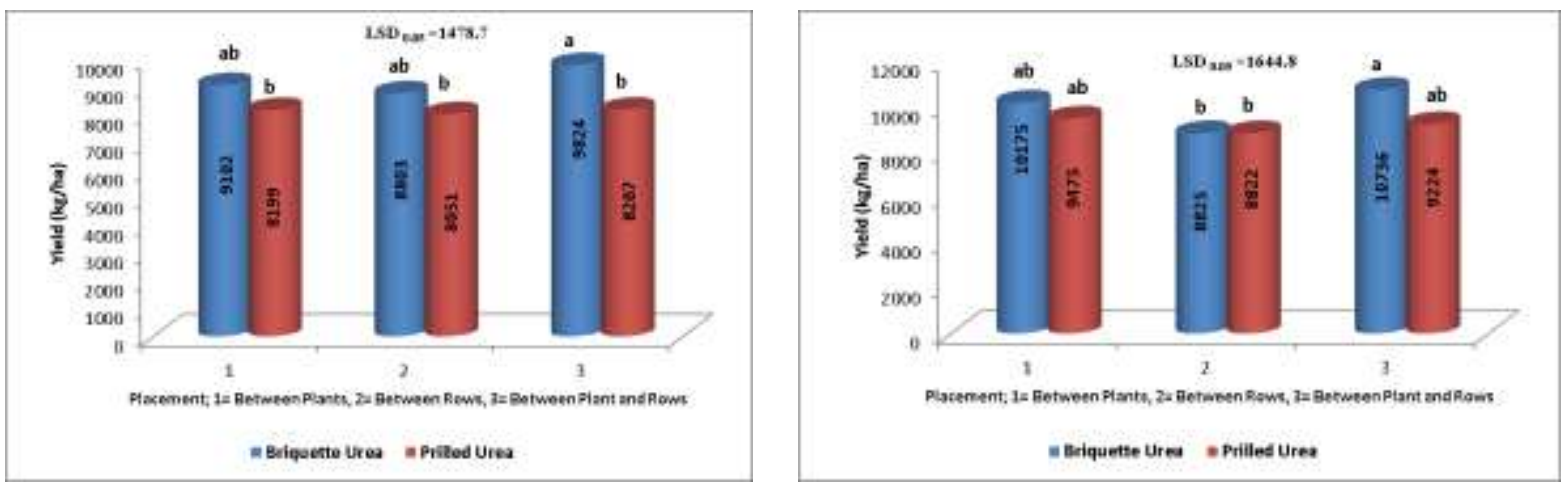

Figure 1:-Mean seed yields as affected by the different Figure 2:-Mean seed yields as affected by the placement sites and forms of nitrogen fertilizer at Yezin, the Department of Agricultural Research different placement sites and forms of nitrogen during winter season 2017 fertilizer at Tatkon Agricultural Research Farm during winter season 2017 


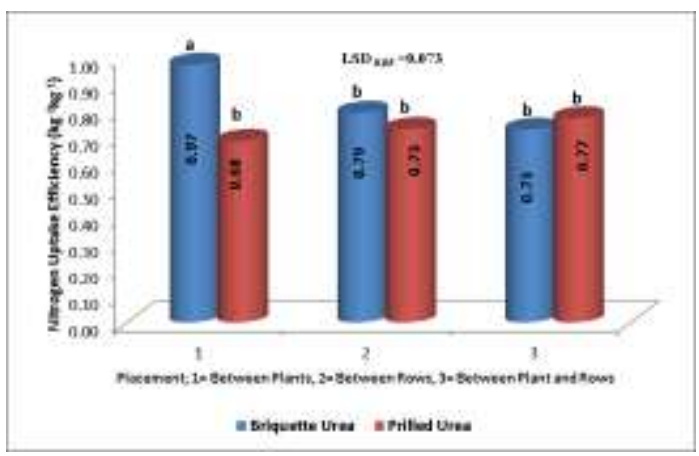

Figure 3:-Mean values of nitrogen uptake efficiency as affected by the different placement sites and forms of nitrogen fertilizer at Yezin, the Department of Agricultural Research during winter season 2017

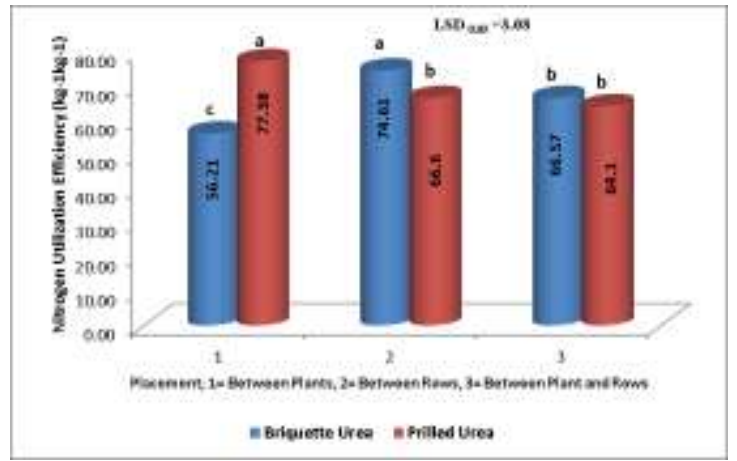

Figure 5:-Mean values of nitrogen utilization efficiency as affected by the different placement sites and forms of nitrogen fertilizer at Yezin, the Department of Agricultural Research during winter season 2017

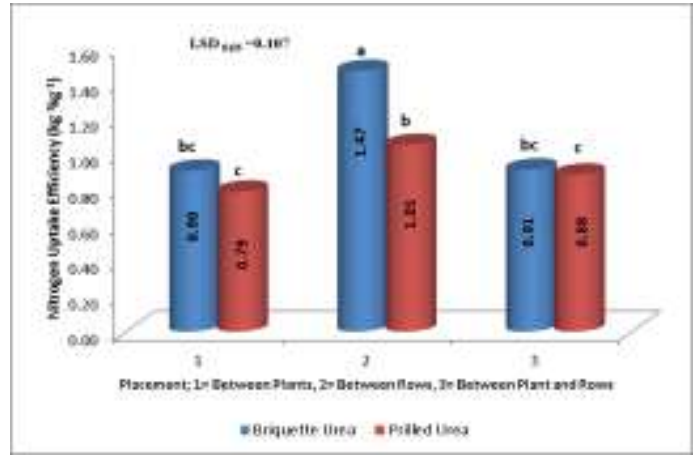

Figure 4:-Mean values of nitrogen uptake efficiency as affected by the different placement sites and forms of nitrogen fertilizer at Tatkon Agricultural Research Farm during winter season 2017

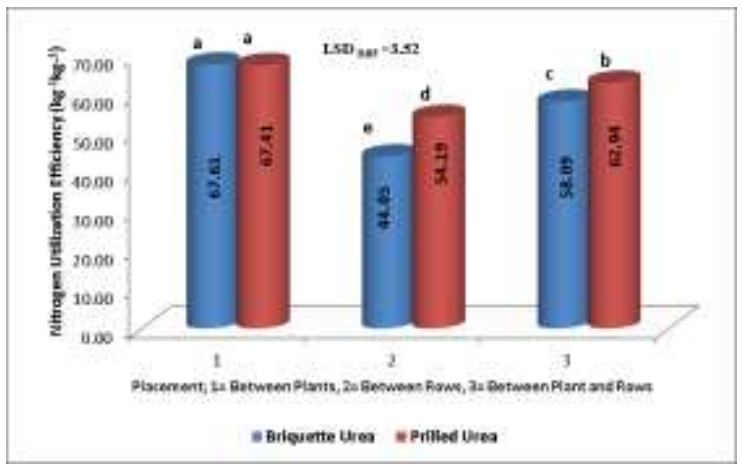

Figure 6:-Mean values of recovery efficiency as affected by the different rates and forms of nitrogen fertilizer at Tatkon Agricultural Research Farm during monsoon season 2017

\section{Conclusion:-}

The results could be summed up that hybrid maize production could be favored by application of briquette urea. Kamprath et al. (1982) showed that $\mathrm{N}$ uptake efficiency was the most important factor contributing to the $\mathrm{N}$ efficiency of maize at low soil $\mathrm{N}$ levels. Even though the physio-chemical properties of two experimental sites is different, briquette urea could be enhanced the $\mathrm{N}$ uptake efficiency. Application of the entire $\mathrm{N}$ in the form of briquette at basal with the rate of $166.29 \mathrm{~kg} \mathrm{~N} \mathrm{ha}^{-1}$ showed better performance with respect to yield and nitrogen uptake efficiency of Yezin Hybrid Maize-10 compared to band placement of split $\mathrm{N}$ prilled urea. The results of this experiment provided valuable information about urea deep placement method which is environmental friendly and will not decrease the normal fertility of land. This study suggests that briquette urea with deep placement method can be used by farmers to improve nitrogen use efficiency and increase seed yield in hybrid maize production. 


\section{References:-}

1. Barbieri, P. A., Echeverria, H. E., Rozas, H. R. S., \& Andrade, F. H. (2008). Nitrogen use efficiency in maize as affected by nitrogen availability and row spacing. Agronomy Journal, 100(4), 1094-1100

2. Bodirsky, B. L., Popp, A., Lotze-Campen, H., Dietrich, J. P., Rolinski, S., Weindl, I., . . . Stevanovic, M. (2014). Reactive nitrogen requirements to feed the world in 2050 and potential to mitigate nitrogen pollution. Nat Commun, 5, 3858

3. Cassman, K. G., Dobermann, A., \& Walters, D. T. (2002). Agroecosystems, nitrogen-use efficiency, and nitrogen management. Ambio, 31(2), 132-140

4. Ciampitti, I. A., \& Vyn, T. J. (2011). A comprehensive study of plant density consequences on nitrogen uptake dynamics of maize plants from vegetative to reproductive stages. Field Crops Research, 121(1), 2-18

5. IFDC., 2013. Annual Report 2013, International Fertilizer Development Center, Alabama, USA

6. Jayasundara, S., Wagner-Riddle, C., Parkin, G., Bertoldi, P., Warland, J., Kay, B., \& Voroney, P. (2007). Minimizing nitrogen losses from a corn-soybean-winter wheat rotation with best management practices. Nutrient Cycling in Agroecosystems, 79(2), 141-159

7. Jayasundara, S., Wagner-Riddle, C., Parkin, G., Bertoldi, P., Warland, J., Kay, B., \& Voroney, P. (2007). Minimizing nitrogen losses from a corn-soybean-winter wheat rotation with best management practices. Nutrient Cycling in Agroecosystems, 79(2), 141-159

8. Kamprath, E.J., Moll, R.H. \& Rodrique, N., 1982. Effects of $\mathrm{N}$ fertilization and recurrent selection on performance of hybrid populations of com. Agron. J. 74,955-958

9. Kirda, C., Topcu, S., Kaman, H., Ulger, A. C., Yazici, A., Cetin, M., \& Derici, M. R. (2005). Grain yield response and $\mathrm{N}$-fertiliser recovery of maize under deficit irrigation. Field Crops Research, 93(2-3), 132-141

10. Koocheki, A., Nassiri Mahallati, M., Mansoori, H., \& Moradi, R. (2013). Assessing nitrogen flow in production and utilization cycle of wheat and maize as a tool to monitor $\mathrm{N}$ loss in Iran. Acta Scientiarum. Biological Sciences, 35(3)

11. Lynch, J. P. (2013). Steep, cheap and deep: an ideotype to optimize water and N acquisition by maize root systems. Ann Bot, 112(2), 347-357

12. Masclaux-Daubresse, C., Daniel-Vedele, F., Dechorgnat, J., Chardon, F., Gaufichon, L., \& Suzuki, A. (2010). Nitrogen uptake, assimilation and remobilization in plants: challenges for sustainable and productive agriculture. Ann Bot, 105(7), 1141-1157

13. McTaggart, I. P., \& Smith, K. A. (1995). The effect of rate, form and timing of fertilizer N on nitrogen uptake and grain $\mathrm{N}$ content in spring malting barley. Journal of Agricultural Science, 125, 341-353

14. Moll, R. H., Kamprath, E. J., \& Jackson, W. A. (1982). Analysis and Interpretation of Factors Which Contribute to Efficiency of Nitrogen-Utilization. Agronomy Journal, 74(3), 562-564

15. Niaz. A, M. Yaseen, M. Arshad and R. Ahmad. 2015. Response of maize yield, quality and nitrogen use efficiency indices to different rates and application timings. The Journal of Animal \& Plant Sciences, 25(4), 1022-1031

16. Pollmer, W. G., Eberhard, D., Klein, D., \& Dhillon, B. S. (1979). Genetic-Control of Nitrogen Uptake and Translocation in Maize. Crop Science, 19(1), 82-86.

17. SAS Institute.2002. SAS/SAT 9 user's guide. SAS Inst.,Cary, NC.

18. Subedi, K. D., \& Ma, B. L. (2005). Nitrogen uptake and partitioning in stay-green and leafy maize hybrids. Crop Science, 45(2), 740-747

19. Wang, X. T., \& Below, F. E. (1992). Root-Growth, Nitrogen Uptake, and Tillering of Wheat Induced by Mixed-Nitrogen Source. Crop Science, 32(4), 997-1002.

20. McTaggart, I. P., \& Smith, K. A. (1995). The effect of rate, form and timing of fertilizer N on nitrogen uptake and grain $\mathrm{N}$ content in spring malting barley. Journal of Agricultural Science, 125, 341-353

21. Mi, G., Chen, F., Wu, Q., Lai, N., Yuan, L., \& Zhang, F. (2010). Ideotype root architecture for efficient nitrogen acquisition by maize in intensive cropping systems. Sci China Life Sci, 53(12), 1369-1373

22. Zotarelli, L., Scholberg, J. M., Dukes, M. D., \& Munoz-Carpena, R. (2008). Fertilizer residence time affects nitrogen uptake efficiency and growth of sweet corn. J Environ Qual, 37(3), 1271-1278 